\title{
Performance of Greenhouse-Grown Beit Alpha Cucumber in Pine Bark and Perlite Substrates Fertigated with Biofloc Aquaculture Effluent
}

\author{
Emmanuel Ayipio ${ }^{1,2, *(D)}$, Daniel E. Wells ${ }^{1}$, Mollie Smith ${ }^{3}$ and Caroline Blanchard ${ }^{1}$ (D) \\ 1 Department of Horticulture, Auburn University, 101 Funchess Hall, Auburn, AL 36849, USA; \\ wellsda@auburn.edu (D.E.W.); ceb0116@auburn.edu (C.B.) \\ 2 CSIR-Savanna Agricultural Research Institute, P.O. Box TL 52, Nyankpala-Tamale, Ghana \\ 3 School of Fisheries, Auburn University, 203 Swingle Hall, Auburn, AL 36849, USA; mrs0018@auburn.edu \\ * Correspondence: eza0035@auburn.edu
}

check for

updates

Citation: Ayipio, E.; Wells, D.E.; Smith, M.; Blanchard, C. Performance of Greenhouse-Grown Beit Alpha Cucumber in Pine Bark and Perlite Substrates Fertigated with Biofloc Aquaculture Effluent. Horticulturae 2021, 7, 144. https://doi.org/ 10.3390/horticulturae7060144

Academic Editors: Nazim Gruda and Juan A. Fernández

Received: 2 May 2021

Accepted: 2 June 2021

Published: 9 June 2021

Publisher's Note: MDPI stays neutral with regard to jurisdictional claims in published maps and institutional affiliations.

Copyright: (C) 2021 by the authors. Licensee MDPI, Basel, Switzerland. This article is an open access article distributed under the terms and conditions of the Creative Commons Attribution (CC BY) license (https:/ / creativecommons.org/licenses/by/ $4.0 /)$.
Abstract: Using aquaculture effluent (AE) to fertigate plants is gaining popularity worldwide. However, in substrate-based systems, the choice of substrate is essential due to their effects on crop productivity. Differences in the retention of nutrients by substrates makes it necessary to assess suitability for use in AE. This study was conducted from January to July in 2016 and September to October in 2019 to evaluate greenhouse-grown Beit Alpha cucumber (Cucumis sativus L. 'Socrates') performance fertigated with $\mathrm{AE}$ in pine bark or perlite substrates, grown either as one plant or two plants per pot. A $2 \times 2$ factorial arrangement in a randomized complete block design with four replications for each season was used. The substrate effect on yield in 2016 depended on the density and season. The pooled yield over seasons in 2016 showed pine bark had a significantly higher yield than perlite by $11 \%$ in one plant per pot but lowered by the same amount in two plants per pot. In 2019, pine bark significantly reduced the leachate $\mathrm{pH}$ in both plant densities and reduced the leachate EC by about $15 \%$ in two plants per pot. The foliar boron was occasionally below sufficiency whilst manganese was above sufficiency in pine bark due to its inherently low $\mathrm{pH}$. We conclude that the effect of the substrates on cucumber yield fertigated with AE is dependent on the season and the number of plants per pot. Therefore, due to the local availability of pine bark, it could be a potential substitute for perlite especially when using one plant per pot for AE. In addition, pine bark could be used as an intermediate substrate to reduce the $\mathrm{pH}$ in $\mathrm{AE}$ for downstream use.

Keywords: Aquaponics; soilless cucumber; leachate pH; cucumber yield

\section{Introduction}

The use of aquaculture effluent (AE) as a nutrient source for plant production is gaining popularity worldwide with an exponential growth from 2004 to 2012 [1]. Aquaponics is a term used to describe a plant production technique in which at least $50 \%$ of a plant's essential nutrients are obtained from an aquaculture system (RAS) [2] and can be coupled with different hydroponic systems. Biofloc technology is used to distinguish the RAS technique in which biofiltration, i.e., the conversion of total ammonium nitrogen into nitrates by nitrifying bacteria, and aquaculture co-habit in the same unit. Therefore, biofloc technology is different from a typical RAS or "clear water" systems in which biofiltration is separated from the aquaculture unit. Biofloc technology shows promising benefits for crop productivity with better growth and quality in lettuce [3].

Substrates differ greatly in their physical and chemical properties leading to differential effects on plant productivity. Substrates of an inorganic or mineral origin such as perlite predominate in hydroponic systems due to their consistent composition and predictable performance. However, perlite substrates tend to have a neutral or near neutral $\mathrm{pH}$, which may not be a good combination with the already high $\mathrm{pH}$ of AE. Aged or composted pine bark is an organic substrate that has been used predominantly in containerized 
ornamental production [4]. However, pine bark substrate has a higher air-filled porosity resulting in a lower water holding capacity than perlite [5]. In a pour through experiment, pine bark substrate had less available water and retained less nitrogen, i.e., $\mathrm{NO}_{3}{ }^{-}-\mathrm{N}$ and $\mathrm{NH}_{4}{ }^{+}-\mathrm{N}$, implying more $\mathrm{N}$ would be drained out [6,7] when used. Although perlite is also porous, due to its smaller particle size it has a higher amount of plant available water [8]. On the other hand, pine bark substrate has a low $\mathrm{pH}$ [5], which may offer a better combination with $\mathrm{AE}$ than perlite.

An assessment of the substrate effect shows that the marketable yield, fruit count and plant height of cucumbers were the highest in a peat substrate that had a significantly higher water holding capacity, cation exchange capacity and organic matter content than perlite and other substrates with a lower water holding capacity [9]. However, in the same study, when perlite was compared with bark mixed with peat of $50 \% v / v$ it resulted in a similar performance of the cucumber crop [9]. Pine bark and perlite substrates also had similar effects on Beit Alpha cucumbers when fertigated with a conventional hydroponic nutrient solution [5]. However, differences in yields exist between conventional hydroponics and aquaponics [10] mostly due to low nutrients, the presence of solids and the high $\mathrm{pH}$ of AE. Thus, substrates that work well when fertigated with a hydroponic solution might not adapt well with AE. Therefore, there is a need to explore substrate suitability and performance in $\mathrm{AE}$ systems. We hypothesize that the type of substrate used would affect the availability of nutrients and, thus, cucumber productivity. Experiments were conducted to explore if pine bark and perlite substrates would influence Beit Alpha cucumber cv. 'Socrates' differently when fertigated with AE. The study also assessed the effect of the plant number per pot and its interaction with the substrate on cucumber productivity.

\section{Materials and Methods}

\subsection{Plant Material, Growth Conditions and Experimental Design}

All trials were conducted at the Auburn University aquaponic project facility located at the E.W. Shell Fisheries Center research station (lat. $32.648935^{\circ} \mathrm{N}$, long. $85.486828^{\circ} \mathrm{W}$ ).

The plant production for the three seasons was done in a $9 \mathrm{~m} \times 29 \mathrm{~m}$ double-layered plastic covered greenhouse. Three-week-old cucumber (Cucumis sativus L. 'Socrates') seedlings were transplanted from 70-cell trays to 11-L rectangular Dutch buckets (Crop King, Lodi, OH, USA) filled with either 100\% horticultural grade perlite or aged pine bark based on the treatment. Over the course of the experiment, plants were trellised upwards to a height of approximately $2.2 \mathrm{~m}$ then allowed to drape.

The production in 2016 ran from 6 January to 31 July in two rounds of trials covering winter to spring seasons. The first round of 2016 ran between winter and early spring while the second round covered the rest of the spring months. The production in 2019 ran from 3 September to 28 October (late summer-fall), with a total of 55 days from transplanting. Plant spacing was $0.46 \mathrm{~m} \times 1.83 \mathrm{~m}$ or $0.84 \mathrm{~m}^{2} /$ pot. During the 2019 trial, the greenhouse temperature and the relative humidity were measured using pendant temperature data and a temperature/RH logger (HOBO, Onset Computer corp. Bourne, MA, USA) placed $2.2 \mathrm{~m}$ from the ground at the draping point. Data were logged every $10 \mathrm{~min}$ and averaged over a $12 \mathrm{~h}$ period. The greenhouse microclimate was considered important to assess the condition of growth of the plants. Although cooling of the greenhouse was done using exhaust fans and a cooling pad controlled by night and day temperature set points, temperatures and the relative humidity still fluctuated throughout the production in 2019. The mean day and night air temperatures over the trial period for 2019 were $28.3^{\circ} \mathrm{C}$ and $20.8^{\circ} \mathrm{C}$, respectively. The relative humidity was generally high. The mean day and night relative humidity values were $64 \%$ and $92 \%$, respectively.

Water was delivered to the cucumbers via an irrigation pump, with the corresponding foot valve submerged $0.35 \mathrm{~m}$ below the surface of a passive clarifier system attached to biofloc tilapia aquaculture unit, as described below, so that the settleable solids further clarified in the bottom of the second clarifier were undisturbed. The irrigation pump was wired to a timer that was scheduled to water for $3 \mathrm{~min}$ on the hour, nine times per day. 
Iron chelate (13\% EDTA Fe) was added at a rate of $2 \mathrm{mg} \mathrm{L}^{-1}$ to the second clarifier at monthly intervals.

The aquaculture unit used to irrigate the plants consisted of a $100 \mathrm{~m}^{3}$ rectangular tank contained in $9 \mathrm{~m} \times 29 \mathrm{~m}$ plastic greenhouse and a water clarifier unit consisting of two cylindro-conical tanks of $0.5 \mathrm{~m}^{3}$ each located just outside the greenhouse. The fish tank was aerated by a 1-hp blower (SweetWater, Aquatic Eco-systems, Apopka, FL, USA) fixed with diffuser tubing. The blower was also used to create an airlift that circulated the water from the tank to the clarifier and back. Using normal operating procedures, effluent and solids from the fish rearing tank flowed into the first clarifier, from which settleable solids were removed 2 to 3 times daily by opening a clarifier drain. The AE then flowed by gravity to a second clarifier where further settleable solids were again removed and clarified effluent either flowed back into the fish tank or pumped into the vegetable greenhouse for irrigation. No other filtration devices were used with this system. Water $\mathrm{pH}$ was maintained in the range of 6 to 6.5 by adding $\mathrm{Ca}(\mathrm{OH})_{2}$ directly to the fish tank. Potassium chloride was added to the fish tank to maintain a concentration of $120-150 \mathrm{ppm}$ when measured for chloride. Water into the fish tanks came from a rainwater fed reservoir and flowed by gravity to the fish tank as make-up water to account for plant use and water loss through evaporation and disposal of fish sludge.

Prior to starting the first experiment in 2016, the fish rearing tanks were in continuous operation, producing Nile tilapia (Oreochromis niloticus L.). Fish were cultured for 11 weeks and then graded, sorted, and stocked by size into three separate netted structures called hapas, from which $50-75 \mathrm{~kg}$ of fish were harvested weekly. To jumpstart fish production, 750 tilapia of $200 \mathrm{~g}$ each were stocked into a $6 \mathrm{~m}^{3}$ hapa to be harvested first during the production cycle. Next 2500 tilapia of $100 \mathrm{~g}$ each and 7000 tilapia of $50 \mathrm{~g}$ each were stocked into separate $18 \mathrm{~m}^{3}$ hapas to be cultured and eventually divided into an additional $100 \mathrm{~m}^{3}$ tank. The fish were fed twice daily at $1.5 \%$ of their body weight with a complete diet of floating pellets containing between $40 \%$ and $36 \%$ protein (Cargill, Franklinton, LA, USA). Thus, the fish culture unit was a mix of different ages and weights that required different feed types and feeding rates.

A $2 \times 2$ factorial treatment arrangement in randomized complete block design with 4 replications per treatment was used leading to 16 experimental units in each season. The treatment combinations were as follows: Treatment 1: Perlite substrate with two plants per pot; Treatment 2: Perlite substrate with one plant per pot; Treatment 3: Pine bark substrate with two plants per pot; Treatment 4: Pine bark substrate with one plant per pot.

\subsection{Measurements and Sampling for Laboratory Analysis (Mineral Composition)}

Once harvesting was started in 2016, cucumber fruits were picked daily. Cucumber fruit count and fresh weights were recorded daily from five middle individual pots, for each experimental unit. In treatments with two plants per bucket, fruit numbers and weights were added together to represent count or weight per pot. In the 2016 trial, leaf samples were taken for foliar analysis at day 50 from transplanting. In total, 15 recently matured leaves from each experimental unit were sampled. Leaf tissues were digested in sulfuric acid and analyzed for macro- and micronutrient concentrations, using the ICP-MS approach (Waters Agricultural Laboratories, Inc., Camilla, GA, USA).

In addition to yield recorded in both 2019 seasons, measurements were taken on plant height measured at each destructive sampling for biomass, from just below the cotyledons to the apical meristems using a meter rule. Total nodes per plant were counted and divided by plant height to obtain average internode length. Leaf area was measured using LI 3100 (LICOR, Lincoln, Nebraska, USA). Leaf samples after area measurements were dried in an oven for minimum of $48 \mathrm{~h}$ at $77^{\circ} \mathrm{C}$. Specific leaf area $\left(\mathrm{cm}^{2} \mathrm{~g}^{-1}\right)$ per pot was calculated by dividing leaf area $\left(\mathrm{cm}^{2}\right)$ over leaf dry weight $(\mathrm{g})$. Leaf SPAD index was measured with a portable SPAD meter (SPAD-502 plus, Spectrum technologies, Aurora, IL, USA) at five points on newly fully expanded leaves and averaged. Leaf stomatal conductance was measured on the same leaves used for SPAD measurements using a handheld leaf 
porometer (Decagon SC-1, Meter Group, Inc. Pullman, WA, USA). Plants were placed on a raised platform constructed using cinder blocks and a fiberglass frame. Containers (4.7-L) were placed below plants to collect leachate daily from which $\mathrm{pH}$ and EC were measured using a HI9813-6 Portable $\mathrm{pH} / \mathrm{EC} / \mathrm{TDS} /$ temperature meter (Hanna Instruments, Smithfield, RI, USA) and $\mathrm{NO}_{3}^{-}$using a L-AQUA twin handheld meters (Horiba, Kyoto, Japan) and multiplied by 0.22 to obtain $\mathrm{NO}_{3}^{-}-\mathrm{N}$.

Nitrogen use efficiency was calculated based on the measured nitrate of the AE. Daily nitrate measurements were average over the period, and together with the irrigation schedule (7:00 a.m. to 6:00 p.m. CDT), discharge rate of $3.785 \mathrm{~L} \mathrm{~h}^{-1}$ [11] the amount fertigated over the period was estimated as;

$$
A_{f}=D / 60 \times r \times E \times T_{p} \times N_{c}
$$

where:

$\mathrm{A}_{\mathrm{f}}=$ Amount fertigated;

$\mathrm{D}=$ duration (minutes) per irrigation event;

$\mathrm{r}=$ discharge rate;

$\mathrm{E}=$ number of events per day;

$\mathrm{T}_{\mathrm{p}}=$ duration of trial;

$\mathrm{Nc}=\mathrm{N}$ concentration.

The nitrogen use efficiency was then estimated by dividing total yield $(\mathrm{kg})$ over amount of $\mathrm{NO}_{3}^{-} \mathrm{N}$ fertigated $(\mathrm{kg})$

\subsection{Data Analysis}

Data were subjected to analysis of variance (ANOVA) using the GLIMMIX procedure in SAS (SAS Institute, Cary, NC, USA). Block and individual sampling units were considered as random variables. For yield and foliar data across seasons in 2016, a three-way ANOVA including substrate, density, and season was used. However, for measurements that were taken in 2019, a two-way ANOVA of substrate by density was used. Post-hoc mean comparison was done using Tukey's HSD at $\alpha=0.05$.

\section{Results and Discussion}

\subsection{Aquaculture Effluent and the Substrate Leachate Nitrate Concentration, $p H$ and EC}

The weekly averages of nitrate- $\mathrm{N}, \mathrm{pH}, \mathrm{EC}$ over the experimental period for 2019 are shown in Table 1. Overall, nitrate-N fluctuated the most, ranging from $59.4 \mathrm{ppm}$ to $77.3 \mathrm{ppm}$ in the AE. The highest average weekly EC was $1.24 \mathrm{mS} \mathrm{cm}^{-1}$. The lowest weekly average $\mathrm{pH}$ was 6.17 , and reached a maximum at 6.7. Measurements of leachate $\mathrm{pH}$, nitrate, and EC allowed the determination of effect of each substrate and planting density on these parameters. In the first configuration, leachate was collected in a non-replicated manner, which was difficult to determine statistical effects of the substrate or density on leachate parameters. However, the setup in 2019 allowed leachate collection from individual experimental units and a test of treatment effect (Table 2).

Leachate $\mathrm{pH}$ was higher in perlite than pine bark by about $9 \%$ irrespective of plant density but was not statistically significant. However, difference in leachate EC between the substrates depended on plant density such that for one plant per pot, no significant difference existed between the two substrates whereas for two plants per pot, perlite recorded significantly higher leachate EC $(12.9 \%)$ than pine bark (Table 2$)$. There was no main effect of substrate, and density or their interaction on leachate nitrate- $\mathrm{N}$ concentration. Generally, the EC of leachate collected from the pots was averagely lower than the effluent EC from the fish tanks, indicating a possible effect of plant nutrient uptake and substrate, especially for pine bark, on leachate EC. 
Table 1. Weekly $\mathrm{AE} \mathrm{NO}_{3}-\mathrm{N}, \mathrm{pH}$, and EC supplied from the aquaculture unit. Daily measurement for 2019 trial from the emitter and averaged over a 7-day period.

\begin{tabular}{|c|c|c|c|}
\hline $\begin{array}{l}\text { Week After } \\
\text { Transplanting }\end{array}$ & $\mathrm{NO}_{3}-\mathrm{N}(\mathrm{ppm})$ & $\mathrm{pH}$ & $\mathrm{EC}\left(\mathrm{mS} \mathrm{cm}^{-1}\right)$ \\
\hline \multicolumn{4}{|l|}{ Week1 } \\
\hline Mean & $61.05 \pm 3.3$ & $6.4 \pm 0.15$ & $1.08 \pm 0.00$ \\
\hline $\mathrm{N}$ & 4 & 4 & 4 \\
\hline \multicolumn{4}{|l|}{ Week2 } \\
\hline Mean & $62.54 \pm 4.9$ & $6.2 \pm 0.14$ & $1.09 \pm 0.09$ \\
\hline $\mathrm{N}$ & 7 & 7 & 7 \\
\hline \multicolumn{4}{|l|}{ Week3 } \\
\hline Mean & $77.31 \pm 3.7$ & $6.3 \pm 0.21$ & $1.24 \pm 0.15$ \\
\hline $\mathrm{N}$ & 7 & 7 & 7 \\
\hline \multicolumn{4}{|l|}{ Week4 } \\
\hline Mean & $69.14 \pm 7.6$ & $6.5 \pm 0.22$ & $1.01 \pm 0.14$ \\
\hline $\mathrm{N}$ & 7 & 7 & 7 \\
\hline \multicolumn{4}{|l|}{ Week5 } \\
\hline Mean & $61.60 \pm 11.9$ & $6.7 \pm 0.27$ & $1.18 \pm 0.39$ \\
\hline $\mathrm{N}$ & 7 & 7 & 7 \\
\hline \multicolumn{4}{|l|}{ Week6 } \\
\hline Mean & $75.43 \pm 17.0$ & $6.5 \pm 0.34$ & $0.98 \pm 0.25$ \\
\hline $\mathrm{N}$ & 7 & 7 & 7 \\
\hline \multicolumn{4}{|l|}{ Week7 } \\
\hline Mean & 61.6 & $6.7 \pm 0.27$ & $1.13 \pm 0.20$ \\
\hline $\mathrm{N}$ & 6 & 6 & 6 \\
\hline \multicolumn{4}{|l|}{ Week8 } \\
\hline Mean & $59.4 \pm 4.4$ & $6.6 \pm 0.10$ & $1.12 \pm 16$ \\
\hline $\mathrm{N}$ & 3 & 3 & 3 \\
\hline
\end{tabular}

Table 2. Simple effects of substrate for each planting density level on leachate $\mathrm{NO}_{3}-\mathrm{N}$, $\mathrm{pH}$, and EC. Data collected from Dutch bucket drainage in 2019.

\begin{tabular}{ccccc}
\hline Density $^{\mathbf{z}}$ & Substrate & $\mathbf{N O}_{\mathbf{3}} \mathbf{- N}(\mathbf{p p m})$ & $\mathbf{p H}$ & $\mathbf{E C}\left(\mathbf{m S ~ c m} \mathbf{~}^{-1}\right)$ \\
\hline $1 \times$ & & & \\
& & & & \\
& Pine bark & $68.91 \mathrm{a}$ & $6.07 \mathrm{~b}$ & $0.81 \mathrm{a}$ \\
& Perlite & $77.11 \mathrm{a}$ & $<0.0001$ & $0.87 \mathrm{a}$ \\
& p-value & 0.4351 & & \\
$2 \times$ & & $6.13 \mathrm{~b}$ & $0.74 \mathrm{~b}$ \\
& & & $6.61 \mathrm{a}$ & $0.85 \mathrm{a}$ \\
& Pine bark & $59.29 \mathrm{a}$ & $<0.0001$ & 0.0169 \\
\hline
\end{tabular}

${ }_{\mathrm{z}} 1 \times=$ one plant per pot; $2 \times=$ two plants per pot; pot $=11$-L Dutch bucket.

\subsection{Foliar Nutrient Analysis of Cucumbers Affected by the Substrate and Density}

The results showed that foliar nutrient concentration of the plants grown in either pine bark or perlite substrates did not differ significantly $(p>0.05)$. In addition, number of plants per pot did not significantly affect foliar nutrient composition of the leaves (Tables 3 and 4). However, plants grown in winter-spring 2016 had higher N, P, K, and Mg values than those in spring except for $\mathrm{Ca}$ and $\mathrm{S}$. Foliar nutrient concentration was higher than sufficiency range for $\mathrm{N}, \mathrm{P}, \mathrm{Ca}$, and $\mathrm{S}$, but not $\mathrm{K}$ and $\mathrm{Mg}$ which were below the sufficiency ranges (Table 3). Foliar micronutrient concentrations were generally within reported sufficiency ranges except for $B$ which was at or below the low side of the reported sufficiency range across all treatments in 2016 (Table 4). The nutrient levels in our system are far below the recommended levels for cucumber production [12] which corroborates other studies show- 
ing that $\mathrm{AE}$ is low in plant essential nutrients, especially micronutrients [13], resulting in low yields of aquaponics systems compared to conventional hydroponics system when there is no nutrient supplementation in the $\mathrm{AE}$ [10]. However, even when two plants were grown per pot, we observed no signs of nutrient deficiency indicating superior performance amidst the low nutrient load. The interesting observation of sufficient foliar nutrient concentration in this study was also reported by Blanchard et al. [14] where regardless of $\mathrm{pH}$ adjustment, cucumber had sufficient foliar nutrient concentration. There needs to be further investigation into what accounts for this performance. We hypothesize that the presence of solids in the AE could play a role in the availability of nutrients through mineralization over time. Additionally, the biological floc which is characteristic of the biofloc system could be a better source of nutrients than clear water systems, as was demonstrated by Pinho et al. [15] which previously led to better growth of lettuce in a biofloc tilapia system [3]. We anticipated that pine bark, due to its organic nature would lead to enhanced mineralization and thus nutrient availability than perlite which is inorganic in such biofloc systems. In addition, we posited that since pine bark generally has lower $\mathrm{pH}$ than perlite, it would present a better substrate level $\mathrm{pH}$ adjustment to the $\mathrm{AE}$ which is usually maintained at higher $\mathrm{pH}$ to favor the fish and nitrifying bacteria. However, our observations showed that although there are isolated cases of higher foliar nutrient content in pine bark than perlite, this is not a general case. The effect of pine bark on $\mathrm{pH}$ could however be responsible for the observed spikes in foliar Mn content in spring 2016 which was above the upper sufficiency levels. Manganese availability is easily influenced by $\mathrm{pH}$ and, therefore, since pine bark has lower $\mathrm{pH}$ than perlite, this could have led to a higher competitive advantage of $\mathrm{Mn}$ than the other divalent cations, such as iron in the pine bark substrate. However, these spikes could be potential source of phytotoxicy [16]. This is due to an attempt by the plant to balance its ionic charge concentration especially when iron $\left(\mathrm{Fe}^{2+}\right)$ is limiting. Foliar B concentration was lower than the lower sufficiency limit in almost all cases except for pine bark in spring 2016. Boron availability is also dependent on $\mathrm{pH}$ which must be below 6.0, preferably between 4.5 and 5.5 for maximum availability [17]. In this case, B sufficiency was favored under the low $\mathrm{pH}$ condition of pine bark which is supported by the leachate measurement taken in 2019 (Table 2).

Table 3. Effect of substrate and planting density on foliar macronutrient concentration ( $\mathrm{g} 100 \mathrm{~g}^{-1}$ dry mass) of 'Socrates' cucumber in two trials in 2016.

\begin{tabular}{|c|c|c|c|c|c|c|}
\hline & $\mathbf{N}$ & $\mathbf{P}$ & $\mathbf{K}$ & $\mathrm{Mg}$ & $\mathrm{Ca}$ & $\mathbf{S}$ \\
\hline \multicolumn{7}{|c|}{ Winter-Spring 2016} \\
\hline \multicolumn{7}{|l|}{ Substrate } \\
\hline Pine bark & 5.26 & 0.86 & 2.63 & 0.43 & 2.07 & $0.55 \mathrm{a}$ \\
\hline Perlite & 5.16 & 0.8 & 2.62 & 0.42 & 2.04 & $0.49 \mathrm{~b}$ \\
\hline$p$-value & 0.4313 & 0.2284 & 0.9796 & 0.8356 & 0.9153 & 0.0197 \\
\hline \multicolumn{7}{|l|}{ Density ${ }^{z}$} \\
\hline $1 \times$ & 5.25 & 0.86 & 2.70 & 0.44 & 2.06 & 0.53 \\
\hline $2 \times$ & 5.18 & 0.8 & 2.55 & 0.42 & 2.05 & 0.51 \\
\hline p-value & 0.6028 & 0.195 & 0.2956 & 0.384 & 0.9636 & 0.2322 \\
\hline \multicolumn{7}{|l|}{ Spring 2016} \\
\hline \multicolumn{7}{|l|}{ Substrate } \\
\hline Pine bark & 4.44 & 0.61 & 2.11 & 0.42 & 4.06 & 0.66 \\
\hline Perlite & 4.45 & 0.57 & 2.14 & 0.43 & 4.21 & 0.6 \\
\hline$p$-value & 0.9697 & 0.5708 & 0.8397 & 0.8091 & 0.5778 & 0.2014 \\
\hline \multicolumn{7}{|l|}{ Density } \\
\hline $1 \times$ & 4.43 & 0.6 & 1.98 & 0.44 & 4.23 & 0.63 \\
\hline $2 \times$ & 4.47 & 0.6 & 2.27 & 0.41 & 4.04 & 0.63 \\
\hline p-value & 0.8694 & 0.9954 & 0.075 & 0.1828 & 0.4921 & 0.9772 \\
\hline Sufficiency level ${ }^{\mathrm{y}}$ & 4.3 & 0.3 & 3.1 & 0.35 & 2.4 & 0.32 \\
\hline
\end{tabular}

${ }^{\mathrm{z}} 1 \times=$ one plant per pot; $2 \times=$ two plants per pot; pot = 11-L Dutch bucket. ${ }^{\mathrm{y}}$ Lower sufficiency level from Mills and Jones Jr [12]. 
Table 4. Effect of substrate and planting density on foliar micronutrient concentration ( $\mathrm{mg} \mathrm{kg}^{-1} \mathrm{dry}^{\mathrm{mass}}$ ) of 'Socrates' cucumber in two trials in 2016.

\begin{tabular}{|c|c|c|c|c|c|}
\hline & B & $\mathrm{Fe}$ & Mn & $\mathrm{Cu}$ & Zn \\
\hline \multicolumn{6}{|c|}{ Winter-Spring 2016} \\
\hline Substrate & & & & & \\
\hline Pine bark & 19.55 & 69.32 & $99.37 \mathrm{a}$ & $9.75 \mathrm{a}$ & $67.3 \mathrm{a}$ \\
\hline Perlite & 22.02 & 67.13 & $71.25 \mathrm{~b}$ & $8.67 \mathrm{~b}$ & $58 \mathrm{~b}$ \\
\hline p-value & 0.0893 & 0.5552 & 0.0205 & 0.0413 & 0.0246 \\
\hline \multicolumn{6}{|l|}{ Density ${ }^{z}$} \\
\hline $1 \times$ & 21.43 & 69.23 & 88.53 & 9.23 & 61.95 \\
\hline $2 \times$ & 20.13 & 67.22 & 82.08 & 9.18 & 63.35 \\
\hline p-value & 0.327 & 0.5849 & 0.5004 & 0.9088 & 0.6695 \\
\hline \multicolumn{6}{|c|}{ Spring 2016} \\
\hline \multicolumn{6}{|l|}{ Substrate } \\
\hline Pine bark & 30.66 & 79.49 & 215.59 & 7.68 & 79.75 \\
\hline Perlite & 27.2 & 74.68 & 193.25 & 8.088 & 80.36 \\
\hline$p$-value & 0.1214 & 0.6239 & 0.2067 & 0.3942 & 0.9221 \\
\hline \multicolumn{6}{|l|}{ Density } \\
\hline $1 \times$ & 28.83 & $79.20 \mathrm{a}$ & 213.5 & 7.73 & 84.43 \\
\hline $2 \times$ & 29.04 & $74.96 \mathrm{a}$ & 195.34 & 8.038 & 75.69 \\
\hline p-value & 0.9187 & 0.6654 & 0.2972 & 0.5149 & 0.1851 \\
\hline Sufficiency levels $\mathrm{y}$ & 30 & 50 & 50 & 8 & 25 \\
\hline
\end{tabular}

${ }^{\mathrm{z}} 1 \times=$ one plant per pot; $2 \times=$ two plants per pot; pot = 11-L Dutch bucket. ${ }^{\mathrm{y}}$ lower sufficiency level from Mills and Jones Jr [12].

\subsection{Yield and Yield Components of a Cucumber Due to the Substrate and Density Effect}

Total yield in 2019 was low due to an early termination of the trial. Maximum yields in 2019 were $3.7 \mathrm{~kg} \mathrm{~m}^{-2}$ and $5.5 \mathrm{~kg} \mathrm{~m}^{-2}$ for one plant per pot and $6.7 \mathrm{~kg} \mathrm{~m}^{-2}$ and $7.1 \mathrm{~kg} \mathrm{~m}^{-2}$ for two plants per pot, respectively, recorded by pine bark and perlite (data not shown). Differences in fruit yield in 2019 was not significantly affected by substrate but plant density (Table 5). The yield advantage of two plants per pot over one plant per pot in 2019 was $63 \%$ on a square meter basis. Yield in 2016 were higher with maximum values ranging from $16.5 \mathrm{~kg} \mathrm{~m}^{-2}$ in one plant per pot to $24.3 \mathrm{~kg} \mathrm{~m}^{-2}$ in two plants per pot. Analysis of variance conducted on only 2016 yields showed that season had no significant main effect on cucumber yield $(p>0.05)$. However, there was a significant three-way interaction among season, planting density, and substrate. In the winter-spring season of 2016, plants grown in perlite substrate recorded $2 \mathrm{~kg} \mathrm{~m}^{-2}( \pm 0.917$; SE) less yield than those grown in pine bark for one plant per pot, although the effect was not statistically significant $(p=0.15)$. However, in spring 2016, perlite recorded statistically significant (adjusted $p=0.040$ ) more yield $\left(2.29 \mathrm{~kg} \mathrm{~m}^{-2}\right)$ than pine bark for two plants per pot. The average yields across seasons are shown in Figure 1.

Effect of the substrates on yield difference is not direct but due to effect on nutrient availability and uptake because of substrates physical, chemical, and biological properties which affect the root environment. On the other hand, number of plants per pot would influence aboveground parameters which relate to light interception for photosynthesis [18]. The interaction between nutrient and water availability due to the substrate effect and aboveground factors due to effect of number of plants per pot, was anticipated to translate into effect on yield. In terms of productivity of the crop, our results showed that both substrates had similar influence on cucumber yield which was similar to observations made by Shaw et al. [5]. In our case, pine bark only showed superior yield performance over perlite in one plant per pot. This means that the increased above and below ground mass due to the additional plant number did not offer benefit for pine bark substrate in the inherently low nutrient AE. Pine bark is known to be high in potassium [19], which is an essential nutrient for fruit development. In cucumber, potassium is especially required 
in increased concentrations at the heavy fruiting stage. Therefore, the high potassium contained in pine bark, coupled with its higher than perlite cation exchange capacity of $10 \mathrm{cmol} \mathrm{L}^{-1}$ [20] was expected to confer superior yield performance in both plant densities. It is not known why there was a reduction in fruit yield for pine bark in two plants per pot. It is most likely that high bulk density, which is characteristic of pine bark, had a restricted growth effect on two plants per pot. Few studies examine the performance of cucumbers in different substrates fertigated with $\mathrm{AE}$, making it difficult to examine the performance of the two substrates in respect to other studies. However, Ayipio et al. [10] showed that substrate-based systems resulted in poor yield comparison between aquaponics and conventional hydroponics crop yield; very few studies used substrates, indicating that more research on substrate use with $\mathrm{AE}$ is required. For cucumber fertigated with hydroponic nutrient solution, performance in different substrates is affected by the substrate's ability to retain water and was demonstrated by improvement in marketable yield by wood bark when combined with peat [9].

Table 5. Interaction effect of planting density and substrate with season on cucumber fruit yield.

\begin{tabular}{lccc}
\hline & \multicolumn{3}{c}{ Yield $\mathbf{~ k g ~ m}^{-2}$ ) } \\
\cline { 2 - 4 } & Winter-Spring 2016 & Spring 2016 & Spring-Summer 2019 \\
\hline Substrate & & $3.37 \mathrm{Ba}$ \\
Pine bark & $13.26 \mathrm{Aa}^{\mathrm{z}}$ & $11.17 \mathrm{Aa}$ & $3.90 \mathrm{Ba}$ \\
Perlite & $12.52 \mathrm{Aa}$ & $12.03 \mathrm{Aa}$ & \\
\hline Density & & & $2.91 \mathrm{Ba}$ \\
\hline $1 \times$ & $10.39 \mathrm{Ab}$ & $9.73 \mathrm{Ab}$ & $4.37 \mathrm{Ba}$ \\
\hline
\end{tabular}

${ }^{\mathrm{z}}$ Means in the same column followed by the same lower-case letter are not statistically different ( $\left.p \geq 0.05\right)$; means in the same row followed by the same upper-case letter are not statistically different. Means under 'Substrate' are not compared with means under 'Density'. ${ }^{\mathrm{y}} 1 \times=$ one plant per pot; $2 \times=$ two plants per pot; pot $=11$-L Dutch bucket.

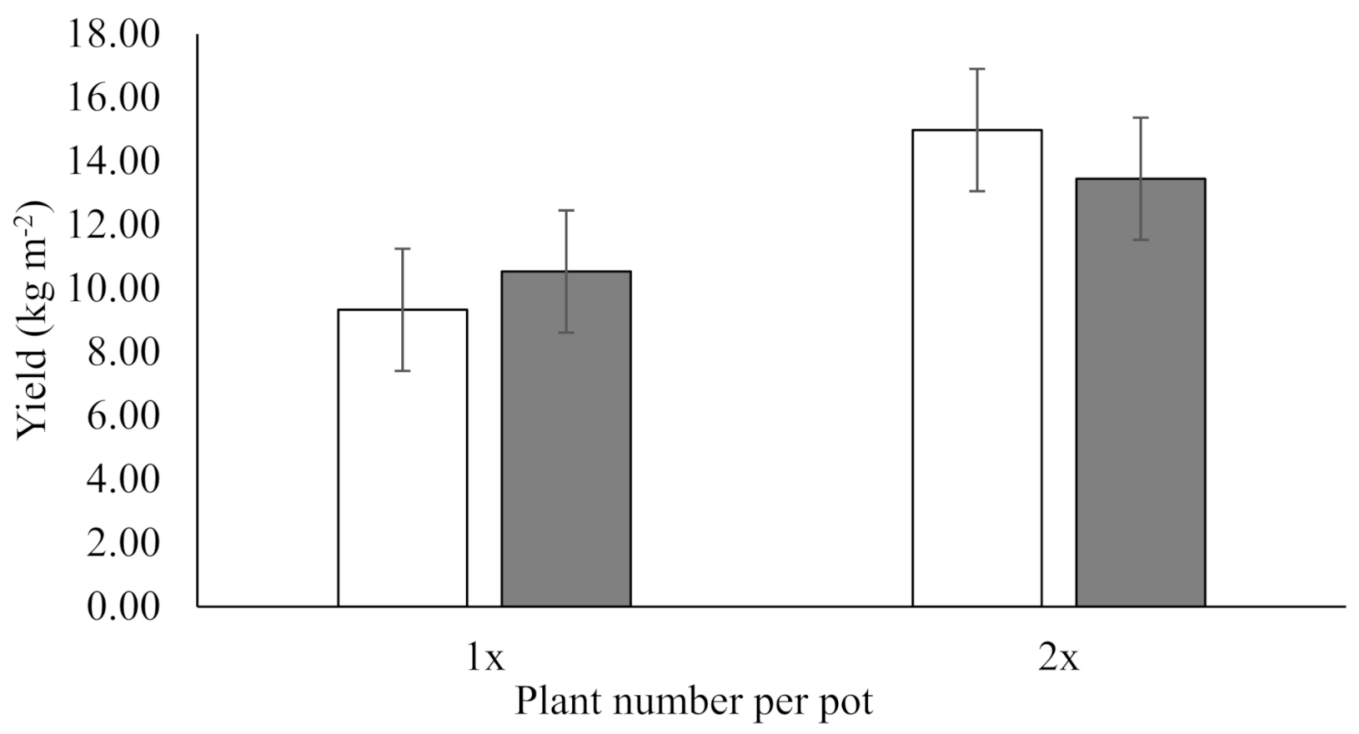

\section{$\square$ Perlite $\square$ PineBark}

Figure 1. Yield per square meters of cucumber in 2016 trial across seasons of spring and winter-spring. Error bars are \pm standard error. $1 \times=$ one plant per pot; $2 \times=$ two plants per pot.

Although our data show that two plants have, overall, greater yield per square meter than one plant per pot, these data are not sufficient to make conclusions on the economic 
productivity of two plants per pot when fertigated with AE. Other economic factors, such as added labor and seed cost, must be considered. We realized that, on a per plant basis, there was no significant effect of number of plants per pot on yield, indicating a lack of mutual benefit of the added leaf foliage to improve yield. Yields obtained in 2019 were generally low for cucumbers grown for 35 days from transplanting due to an early termination of the experiment resulting from observed foliar damage from disease spores. Even the low yield results, obtained in 2019, compare well with an earlier study in the same system [11] where cucumber plants were grown for 44 days from transplanting.

\subsection{Morphological Measurements}

In the 2019 trial, SPAD value was used as a proxy assessment of the overall health of the plants since there was no foliar nutrient content analysis. Mean SPAD values were 23.27 and 25.77 in one plant per pot, whereas for two plants per pot, SPAD values were 24.73 and 25.98 for perlite and pine bark, respectively. Generally, plants grown in pine bark had significantly higher SPAD values than those in perlite by about 1 SPAD unit which is considered low in terms of horticultural importance. A value of 45.2 SPAD units is considered sufficient to predict yields for cucumber [21]. Therefore, the low SPAD values recorded in 2019 could also explain the low yields recorded in that year. Leaf area and dry weights were used to estimate specific leaf area (SLA) which is usually an essential input for leaf area index conversion when modeling light interception. The SLA of cucumber plants grown in the system ranged from $249.69 \mathrm{~cm}^{2} \mathrm{~g}^{-1}$ to $430.35 \mathrm{~cm}^{2} \mathrm{~g}^{-1}$ which was similar to that found in fruiting cumber plants for restricted and non-restricted roots at 60 days after sowing [22]. Low SLA values are an indication of high leaf dry matter content as a result high light level. It was expected that SLA be high in two plants per pot due to competition for light. However, our results showed no significant effect of number of plants per pot on SLA indicating similarity in light environment for both configurations. Mean Stomata conductance values were 712.4 and $696.1 \mathrm{mmol}\left[\left(\mathrm{H}_{2} \mathrm{O}\right)\right]$ $\mathrm{m}^{-2} \mathrm{~s}^{-1}$ in perlite but were 674.0 and $729.22 \mathrm{mmol}\left[\left(\mathrm{H}_{2} \mathrm{O}\right)\right] \mathrm{m}^{-2} \mathrm{~s}^{-1}$ in pine bark for one plant and two plants per pot, respectively. However, there was no significant interaction between substrate and number of plants per pot on stomata conductance. The values obtained for stomata conductance are similar to values obtained for cucumber infested with powdery mildew even with full strength nutrient supply [23]. This stomata response was because of the greenhouse growing condition of high humidity and temperature but not due to treatment effects. However, it was evident that in pine bark substrate, growing two plants per pot exacerbated the situation as seen in the reduction in stomata conductance. The low stomata conductance is an additional explanation for the low yield observed in 2019, because stomata opening is necessary for both transpiration and leaf photosynthesis. Leaf area index (LAI) values were also low, with the highest LAI being $3.0 \mathrm{~m}^{2} \mathrm{~m}^{-2}$ and the lowest being $1.07 \mathrm{~m}^{2} \mathrm{~m}^{-2}$ at 35 days after transplanting with more than 16 leaves. For optimal cucumber productivity, a LAI of greater than $3.5 \mathrm{~m}^{2} \mathrm{~m}^{-2}$ is estimated for more than 16 leaves per plant [18]. This means the current LAI estimated from our study is not optimal for cucumber productivity. However, Nikolaou et al. [24] obtained maximum LAI value of $1.84 \mathrm{~m}^{2} \mathrm{~m}^{-2}$ at 43 days after transplanting in greenhouse soilless cucumber grown with cooling indicating our results are not an isolated case.

\section{Conclusions}

We can conclude that generally, although the biofloc AE was low in dissolved ions, it was successful for growing the Beit Alpha cucumbers and had comparable yields between the two substrates assessed. Foliar nutrient concentrations were generally within sufficiency ranges, except foliar $\mathrm{B}$ which was lower. Pine bark showed effect on reducing leachate $\mathrm{pH}$ and could be used as a $\mathrm{pH}$ downward regulator in $\mathrm{AE}$ for downstream. Effect of the substrates on yield was dependent on season and number of plants per pot. Use of pine bark as a substitute substrate for perlite is only justified in one plant per pot, when density is increased to two plants per pot perlite is more preferrable. 
Author Contributions: Conceptualization, and design; D.E.W., data curation; E.A., M.S., C.B.; data analysis, initial draft; E.A.; Revision; D.E.W., E.A., M.S., C.B. All authors have read and agreed to the published version of the manuscript.

Funding: This research was funded by the United States Department of Agriculture National Institute of Food and Agriculture (USDA-NIFA), grant number 2016-70007-25758.

Institutional Review Board Statement: Not applicable.

Informed Consent Statement: Not applicable.

Data Availability Statement: Data is available upon request to the corresponding author.

Acknowledgments: The authors are also grateful to the Alabama Agricultural Extension Service (AAES) for their support and to all the graduate student workers for help in the greenhouse.

Conflicts of Interest: The authors declare no conflict of interest.

\section{References}

1. Love, D.C.; Fry, J.P.; Genello, L.; Hill, E.S.; Frederick, J.A.; Li, X.; Semmens, K. An international survey of aquaponics practitioners. PLOS ONE 2014, 9, e102662. [CrossRef]

2. Palm, H.W.; Knaus, U.; Appelbaum, S.; Goddek, S.; Strauch, S.M.; Vermeulen, T.; Haïssam Jijakli, M.; Kotzen, B. Towards commercial aquaponics: A review of systems, designs, scales and nomenclature. Aquac. Int. 2018, 26, 813-842. [CrossRef]

3. Pinho, S.M.; Molinari, D.; de Mello, G.L.; Fitzsimmons, K.M.; Coelho Emerenciano, M.G. Effluent from a biofloc technology (BFT) tilapia culture on the aquaponics production of different lettuce varieties. Ecol. Eng. 2017, 103, 146-153. [CrossRef]

4. Papadopoulos, A.P.; Asher, B.-T.; Silber, A.; Uttam, K.S.; Michael, R. Inorganic and Synthetic Organic Components of soilless culture and potting mixes. In Soilless Culture:Theory and Practice; Raviv, M., Lieth, H.J., Eds.; Elsevier B.V.: London, UK, 2008; pp. 505-537.

5. Shaw, N.L.; Cantliffe, D.J.; Funes, J.; Shine, C.I.I.I. Successful Beit Alpha cucumber production in the greenhouse using pine bark as an alternative soilless media. HortTechnology 2004, 14, 289-294. [CrossRef]

6. Jahromi, N.B.; Fulcher, A.; Walker, F.; Altland, J. Optimizing substrate available water and coir amendment rate in pine bark substrates. Water 2020, 12, 362. [CrossRef]

7. Niemiera, A.X.; Bilderback, T.E.; Leda, C.E. Pine bark physical characteristics influence pour-through nitrogen concentrations. HortScience 1994, 29, 789-791. [CrossRef]

8. Grillas, S.; Lucas, M.; Bardopoulou, E.; Sarafopoulos, S.; Voulgari, M. Perlite based soilless culture systems: Current commercial application and prospects. Acta Hortic. 2001, 548, 105-113. [CrossRef]

9. Peyvast, G.; Olfati, J.A.; Roudsari, O.N.; Kharazi, P.R. Effect of substrate on greenhouse cucumber production in soilless culture. Acta Hortic. 2010, 871, 429-436. [CrossRef]

10. Ayipio, E.; Wells, D.E.; McQuilling, A.; Wilson, A.E. Comparisons between Aquaponic and Conventional Hydroponic Crop Yields: A Meta-Analysis. Sustainability 2019, 11, 6511. [CrossRef]

11. Pickens, J.M. Integrating Effluent from Recirculating Aquaculture Systems with Greenhouse Cucumber and Tomato Production. Ph.D. Thesis, Auburn University, Auburn, AL, USA, 2015.

12. Mills, H.A.; Jones, J.B., Jr. Plant Analysis Handbook II: A Practical Sampling, Preparation, Analysis, and Interpretation Guide; MicroMacro Publishing, Inc.: Athens, GA, USA, 1996; ISBN 1878148052.

13. Bittsánszky, A.; Uzinger, N.; Gyulai, G.; Mathis, A.; Junge, R.; Villarroel, M.; Kotzen, B.; Kőmíves, T. Nutrient supply of plants in aquaponic systems. Ecocycles 2016, 2, 17-20. [CrossRef]

14. Blanchard, C.; Wells, D.E.; Pickens, J.M.; Blersch, D.M. Effect of pH on cucumber growth and nutrient availability in a decoupled aquaponic system with minimal solids removal. Horticulturae 2020, 6, 10. [CrossRef]

15. Pinho, S.M.; de Lima, J.P.; David, L.H.; Oliveira, M.S.; Goddek, S.; Carneiro, D.J.; Keesman, K.J.; Portella, M.C. Decoupled FLOCponics systems as an alternative approach to reduce the protein level of tilapia juveniles' diet in integrated agri-aquaculture production. Aquaculture 2021, 543, 736932. [CrossRef]

16. Maher, M.J.; Thomson, D. Growth and manganese content of tomato (Lycopersicon esculentum) seedlings grown in Sitka spruce (Picea sitchensis (Bong.) Carr.) bark substrate. Sci. Hortic. 1991, 48, 223-231. [CrossRef]

17. Maucieri, C.; Nicoletto, C.; van Erik, O.; Anseeuw, D.; Robin, V.H.; Junge, R. Hydroponic Technologies. In Aquaponics Food Production Systems: Combined Aquaculture and Hydroponic Production Technologies for the Future; Goddek, S., Joyce, A., Kotzen, B., Burnell, G.M., Eds.; SpringerOpen: Chan, Switzerland, 2019; pp. 76-110. ISBN 978-3-030-15942-9.

18. Xiaolei, S.; Zhifeng, W. The optimal leaf area index for cucumber photosynthesis and production in plastic greenhouse. Acta Hortic. 2004, 633, 161-165. [CrossRef]

19. Maher, M.; Prasad, M.; Raviv, M. Organic soilless media components. In Soilless Culture Theory and Practice; Raviv, M., Lieth, J.H., Eds.; Elsevier: Amsterdam, The Netherlands, 2008; pp. 459-504.

20. Silber, A. Chemical Characteristics of Soilless Media. In Soilless Culture Theory and Practice; Raviv, M., Lieth, H.J., Eds.; Elsevier: Amsterdam, The Netherlands, 2008; pp. 210-239. 
21. Padilla, F.M.; Peña-Fleitas, M.T.; Gallardo, M.; Giménez, C.; Thompson, R.B. Derivation of sufficiency values of a chlorophyll meter to estimate cucumber nitrogen status and yield. Comput. Electron. Agric. 2017, 141, 54-64. [CrossRef]

22. Kharkina, T.G.; Ottosen, C.O.; Rosenqvist, E. Effects of root restriction on the growth and physiology of cucumber plants. Physiol. Plant. 1999, 105, 434-441. [CrossRef]

23. Wang, Y.; Ma, G.; Du, X.; Liu, Y.; Wang, B.; Xu, G.; Mao, H. Effects of Nutrient Solution Irrigation Quantity and Downy Mildew Infection on Growth and Physiological Traits of Greenhouse Cucumber. Agronomy 2020, 10, 1921. [CrossRef]

24. Nikolaou, G.; Neocleous, D.; Katsoulas, N.; Kittas, C. Modelling transpiration of soilless greenhouse cucumber and its relationship with leaf temperature in a mediterranean climate. Emir. J. Food Agric. 2017, 29, 911-920. [CrossRef] 